\title{
CONCENTRATION OF HEAVY METALS FROM TRAFFIC EMISSIONS ON PLANT PRODUCE SOLD ALONG IFE - IBADAN EXPRESS WAY: HEALTH IMPLICATIONS
}

\author{
BELLO O.A ${ }^{1}$, A.A. AIYELOJA ${ }^{2 *}$ AND F.A ADETAYO ${ }^{3}$ \\ ${ }^{1}$ Department of Biology, Osun State College of Education, Ila Orangun, Nigeria. \\ ${ }^{2}$ Department of Forestry and Wildlife Management. \\ University of Port Harcourt, Nigeria. \\ ${ }^{3}$ Department of Biology Education, University of Uyo, Nigeria.
}

\section{*Corresponding Author}

\begin{abstract}
In recent years, emission and combustion of fossils and fuels have been identified as primary sources of atmospheric metallic burden. Detailed information about this is not readily available in Nigeria. This study was therefore carried out to determine the concentration of heavy metals (e.g. lead, mercury and cadmium\} deposited on plant produce sold along the highway in Osun State). Samples were bought from traders along the road from two different locations (Gbongan and Ikire junctions). The samples were digested and analyses for lead $(\mathrm{Pb})$, cadmium (cd) and Mercury ( $\mathrm{Hg})$ using Atomic Absorption Spectrophotometers (AAS). The data collected were analyzed using descriptive statistics (Bar charts and graph). Results from the various analyses indicated that the levels of these metals were found to increase uphill due to high combustion of fuel leading to high emission of vehicular exhaust and vice versa (uphill > downhill). When the heavy metal content in samples was compared with FAO/WHO guideline for food, it was observed that the metal contents in the plant produces sold along the road were higher than the threshold level, hence the plant produces sold along the road were considered contaminated. Therefore, buying and selling of plant produces along the highways should be discouraged. Enactment of an enabling law and its enforcement should be considered as priority by the appropriate organs of the government
\end{abstract}

Key words: Vehicle, Travel, Highway, Deposition, Food.

\section{INTRODUCTION}

Pollution may be defined as the release into the environment (air, water and soil) of substances or energy in such quantities and for such duration that they cause harm to people and/or other organisms. Pollution brings about changes or alterations in the physical, chemical and/or biological condition in the environment that affects the quality of life of humans, animals and/or plants (Harrison, 1982; Uwagboe and Hymore, 2008). Major pollutants include factories wastes (gases and waste waters), exhaust fumes of vehicles (cars, lories and other forms of automobiles), untreated domestic waste waters, solid waste from industries, homes and commercial centres. The effect of toxic contaminants (metals, organic compounds, micro organisms) on human health can be classified as either acute or chronic. The reaction to a substance causing serious illness or death in an individual within 48 hours after exposure is considered acute toxicity while on the other hand; chronic toxicity is a long term effect on health due to frequent exposure to small amounts of toxic substances (Babich, 2008). Air pollutions are mainly caused by the discharge of gases and particles from factories, domestic fire, motor vehicles, dust from road construction and land preparation in agriculture. Important atmospheric pollutants include gases such as chlorofluorocarbon (CFC), Sulphur (IV) Oxide $\left(\mathrm{SO}_{2}\right)$, hydrocarbon ( $\left.\mathrm{HC}\right)$ and the oxides of nitrogen $\left(\mathrm{NO}_{\mathrm{x}}\right)$. Increase of Carbon (II) Oxide in the atmosphere as a result of human activity constitutes a 
major source of atmospheric pollution. Exhaust fumes of vehicles contain Carbon (II) Oxide (CO) which is poisonous to the body when in excess. Some may contain lead compounds which are also very poisonous. Radioactive fallout from weapon testing, ground-level ozone, particulate matter, sulfur dioxide and nitrogen oxides, are also important air pollutants (Jeantheau, 2010).

The expansions of industrial and agricultural activities usually lead to increase in pollution. This is because certain waste products received into atmosphere usually contain toxic chemical such as mercury, lead, etc. which can be stored or accumulated in the system of an organism(plant or animal) which may later find their ways into man (Jeantheau, 2010). Heavy metallic ions especially lead, mercury, cadmium and so on, constitute air pollution. The heavy metal toxicity has a very specific effect causing more or less complete inhibition of root growth (Cheung et al. 1989).

Municipal, agricultural and industrial wastes including many toxic synthetic chemicals which cannot be broken down by natural processes are polluting our air. Even in tiny amounts some of these substances can cause serious harm. Also our everyday activities like bush burning, exhaust from automobiles, among others cause air pollution. In facts, of the almost ten million chemicals known today, approximately 100,000 chemicals are used commercially (Brahic, 2006).

The term heavy metal refers to any metallic element that has a relatively high density and is toxic or poisonous at low concentration. Examples of heavy metals include Mercury (Hg), Cadmium (Cd), Arsenic (As), Chromium (Cr), Thallium (Ti) and lead (Pb) (Grandjean and Landrigan 2006). Heavy metals are natural components of the "Earths" crust. They cannot be degraded or destroyed to a small extent. They enter into human bodies via food, drinking water and air. As trace elements, some heavy metals e.g. copper, selenium, zinc are essential to maintain the metabolism of the human body. However, at higher concentration, they can lead to poisoning. Heavy metal poisoning could result from drinking contaminated water, high ambient air concentration near emission sources or intake via the food chain.

Heavy metals are dangerous because they tend to bio-accumulate i.e. increase in concentration in a biological organism over time, compared to the chemical concentration in the environment. Compounds accumulate in living things anytime they are taken up and stored faster than they are broken down (metabolized) or excreted. Heavy metals can be deposit on food or farm produces because most farm produces along the road are often polluted by pollutants which may be anthropogenic or natural. Anthropogenic pollution is caused by the release of liquid, solid and gaseous waste into the environment by industries, home, farmland, automobile and bush burning among others.

It has been established that motor vehicles introduce a number of toxic metals into the atmosphere through exhaust discharges; these include lead, cadmium, mercury and Zinc and these heavy metals are potentially harmful to most organisms at some level of exposure and absorption (Fowler 1973, Duruibe et al. 2007). At low concentrations many heavy metals including mercury, lead, Arsenic and copper inhibit photosynthesis and phytoplankton growth (Clijsters and VanAssche. 1985), delay embryonic development, malformation and reduced growth of adult fish, mollusk and crustaceans under similar conditions. (Khan et al. 2006)

The human health aspect linked to the consumption of heavy metals, from contaminated food is of great concern. Man being at the top of many food chains is highly vulnerable to such heavy metals (Singh et al., 2010). In Nigeria, the increasing consumption of plant produce by the population as well as its importance in animal feed underscore the importance of the potential risks of heavy metals in plants produce sold along the high way. There are two classes of toxic substances in food. Endogenous and exogenous contaminants (toxins) of foods. Endogenous toxins are found naturally in food while exogenous toxins are 
environmental contaminants in foods. All heavy metals are exogenous toxins which could be avoided.

The results of this investigation would help in monitoring the presence of heavy metal in foods since they are directly or indirectly responsible for a large proportion of energy intake by humans and other animals.

\section{MATERIALS AND METHODS}

\section{The Study Area}

The ever busy Ife-Ibadan express way was chosen for the study. The road is located within latitude $7^{\circ} 21^{\prime} \mathrm{n}$ and $7^{\circ} 30^{\prime} \mathrm{N}$ and longitudes $4^{\circ} 07^{\prime} \mathrm{E}$ and $4^{\circ} 35^{\prime} \mathrm{E}$. This road is both intra and interstate and the main socio-economic activities along this road are farming, food processing and petty trading/marketing of farm produce. Samples were taken at different segments of the road; Uphill and downhill. This is because vehicular speed change occurs mostly in these places. Plant produces - yam, plantain, pepper and oranges were brought directly from the traders at Gbongan junction and Ikire junctions after they were displayed for a considerable period of time.

\section{Decarbonization of samples}

Each sample of the plant produce was mashed into paste with the aid of mortar and pestle. Specific gram of the paste was weighted on the weighing balance in a conical flask of known weigh and the sample was transferred into a clean local pot. It was then placed on the lighted store and allowed to char (i.e.) burning off all the carbon contents and other organic contents of the sample. This procedure was repeated for other samples of plant produce.

\section{Ashing of The Samples}

The char recovered from the procedure was transferred into a crucible of known weight; the crucible was well labeled and placed in a dim furnace and ash at $600^{\circ} \mathrm{C}$ for 3 hours. It was then removed and allowed to cool in desiccators. This was repeated for all the samples.

\section{Digestion of samples}

Two grams of the samples (ash) was weight into a conical flask, $5 \mathrm{ml}$ of Hydrochloric Acid $(\mathrm{HCl})$ acid was added and left for 30 minutes for proper digestion to take place. After the digestion, the funnel and the filter paper (workman number one filter paper) was placed on a beaker for the filtration. The filtrate was transferred properly to the $50 \mathrm{ml}$ conical flask which was made up with distil water then shake vigorously to be well mixed. The procedure was repeated for all the samples and the sample solutions were stored in stock plastic bottles for analysis.

\section{Analysis Of Samples By AAS}

The sample solutions were atomized in a burner as this ruptures chemical bonds and breaks down molecules into atoms, which exists mainly in their ground state. Atoms in this condition absorb characteristics resonant radiation of precisely the same wavelength that they would emit. They were excited, this was utilized by allowing resonant radiation of a metallic elements generally in a hollow cathode lamp source to pass through the flame vaporize sample. The extent of absorption is characteristics of the analytic and is proportional to the concentration of the element being aspirated in the flame. The instrument was put on for 15 minutes so as to warm it up and each lamp was set at its specific wavelength and current. The fuel and air supplies were set at specific flow rates. This is to maintain a constant pressure in the nebulizer to prevent decrease in the aspiration rate. The instrument was first standardized with the serial dilution of the standard, ranging from $0.10 \mathrm{mg} / \mathrm{l}$ for each of the elements in the sample solution which were measured and recorded. 
RESULTS AND DISCUSSION

Table 1: Concentration of Metals in Plant Produces sold on Ife-Ibadan Highway (Ikire Junction -Up Hill).

\begin{tabular}{|c|c|c|c|}
\hline \multirow{2}{*}{$\begin{array}{l}\text { PLANT } \\
\text { PRODUCES }\end{array}$} & \multicolumn{3}{|l|}{ METALS } \\
\hline & Lead $(\mathrm{mg} / \mathrm{g})$ & Mercury $(\mathrm{mg} / \mathrm{g})$ & Cadmium (mg/g) \\
\hline Yam & 58.52 & 3.83 & 1.46 \\
\hline Plantain & 50.02 & 3.51 & 1.37 \\
\hline Orange & 47.65 & 3.40 & 1.32 \\
\hline Pepper & 42.23 & 3.05 & 1.35 \\
\hline
\end{tabular}

Standard value $(\mathrm{WHO} / \mathrm{FAO})=\mathrm{Pb}=0.3 \mathrm{mg} / \mathrm{g} ; \mathrm{Cd}=0.005 \mathrm{mg} / \mathrm{g} ; \mathrm{Hg}=2.0 \mathrm{mg} / \mathrm{g}$

Table 2: Concentration of Metals in Plant Produces Ife-Ibadan Highway (Gbongan JunctionDownhill)

\begin{tabular}{llll}
\hline PLANT & \multicolumn{2}{l}{ METALS } & \\
\cline { 2 - 4 } PRODUCES & Lead $(\mathrm{mg} / \mathrm{g})$ & Mercury $(\mathrm{mg} / \mathrm{g})$ & Cadmium $(\mathrm{mg} / \mathrm{g})$ \\
\hline Yam & 26.32 & 3.50 & 1.38 \\
Plantain & 24.42 & 3.07 & 1.29 \\
Orange & 20.13 & 3.07 & 1.23 \\
pepper & 18.95 & 2.93 & 1.19 \\
\hline
\end{tabular}

Standard value $(\mathrm{WHO} / \mathrm{FAO})=\mathrm{Pb}=0.3 \mathrm{mg} / \mathrm{g} ; \mathrm{Cd}=0.005 \mathrm{mg} / \mathrm{g} ; \mathrm{Hg}=2.0 \mathrm{mg} / \mathrm{g}$

The metal contents of plant produces sampled along the roadside of Ife-Ibadan highway are shown in tables 1 and 2. Higher level of metals was recorded for plant produces along Ikire roadside compared to those along Gbongan roadside. This is because most vehicles emit more fumes uphill. All the concentrations were much higher than the FAO/WHO standard values. (FAO/WHO, 1976, Zahir et al, 2009), with Lead having the highest concentration followed by Mercury and Cadmium respectively.

\section{Effect of vehicular emission along roadside}

From this study, it is clear that through vehicular emission, gasoline associated metals such as $\mathrm{Pb}, \mathrm{Cd}, \mathrm{Hg}, \mathrm{Ni}, \mathrm{Zn}$ are introduced in to the environment. This may have adverse effect on the flora and fauna within the areas of deposition, most especially on the health of artisans such as vulcanizers and mechanics, who site their workshops along highways to attract customer as well as the plant produces sellers. Others who live in close proximity to dense automobile traffic density areas are also exposed to appreciably higher concentration than others. The practice of sun -drying food stuff, which is a very common feature along our road by farmers and rural dwellers, is another means of taking in heavy metals. Such food stuff includes fermented cassava and yam, peppers, onions and maize grain among others. Once the food is taken, the metal may accumulate in animal and human tissues to toxic levels. The location of fish ponds very close to highways is another means by which metal could probably enter into the food chain. Closely related to this is farming along roadsides especially within the right of way (ROW). Apart from the direct exposure of the farmers while working on the farms, the plant and soil are also contaminated. These plants are eventually consumed by man and grazing animal. Furthermore, the barks and leaves of most trees growing along roadsides are used as local herbs, taking or boiled to cure a varieties of diseases, there could be health risk when these trees are burdened by metals known to have lethal effects. (Gidding, 1973; Gustau 1974). 


\section{CONCLUSION}

From this work, it was noted that the plant along the roadside where samples were taken invariably showed high level of metals investigated. The concentration of these metals increases with increasing days of the plant produces along the road.

It was also observed that the extent of heavy metal contamination was positively related to the road segment (uphill, downhill). For instance, the plant produces collected from uphill (Ikire junction) had higher concentrations of the metals than the plant produces collected from downhill (Gbongan junction). To prevent most of the metals being emitted via vehicular movement from getting into the food chain, the following recommendations are made: Enforcement of the edict banning sun-drying of food stuff such as pepper, okra, fermented cassava flour etc. along roadsides and the use of smoking vehicles to prevent severe environment pollution. Legislation against the sale of farm produces along the highway and the sale of gasoline containing heavy metals.

\section{REFERENCES}

Babich M.A. (1998): The Risk of Chronic Toxicity Associated with Eposure to Diisononyl Phthalate (DINP) in Children's Products. Directorate for Epidemiology and Health Sciences. U.S. Consumer Product Safety Commission. Bethesda. 37pp.

Brahic C. (2006). Warning over chemical risk to developing brains. New Scientist Health. www.newscientist .com retrieved 29/11/10.

Cheung Y.H, M. H. Wong and N. F. Y. Tam. (1989): Root and Shoot Elongation as an Assessment of Heavy Metal Toxicity and 'Zn Equivalent Value' of Edible Crops. Hydrobiologia Vol.188/189, No. 1, 377-383.

Clijsters H. and F. VanAssche (1985): Inhibition of Photosynthesis by Heavy Metals. Photosynthesis Research. Vol. 7, 31-40.

Duruibe. J.O., M.O.C. Ogwuegbu and J.N. Egwurugwu.(2007). Heavy metals pollution and human biotic effects. International Journal of Physical Sciences. Vol. 2(5), 112-118. www.academicjournals.org/IJPS

FAO/WHO (1976): List of Maximum Levels of Recommended for Contaminants by the Joint of FAO/WHO codex Alimenetarius commission, 2nd series, CALIFAL, Rome, 3, 1-8. Fowler B.A. (1973): Health Perspective. National Institute of Environmental Health Sciences. North Carolina. 107-108.

Giddlings, J. C (1973): Chemistry, Man and Environmental Change, Sam Francisco Camfield Press.

Grandjean P. and P.J. Landrigan (2006): Developmental Neurotoxicity of Industrial Chemicals. The Lancet. Vol. 16:368. Issue 9553. 2167-2178.

Grustav, R. (1974): Hazardous Heavy Metals. WHO International Reference Centre.

Harrison, R .M (1982): Pollution: Causes. Effects and Control: The Royal Society of Chemistry. (1st Edition), London.

Jeantheau M. (2010): Saving the Planet. One joke at a time: in the air wing, Major Pollutants outrank general pollutants. www.grinningplanet.com/2007/07major-qirpollutants article.htm. retrieved $\underline{30 / 11 / 2010}$.

Khan M.A., S.A. Ahmed, B. Catalin, A. Khodadoust, O. Ajayi and M. Vaughin. (2006): Effect of Temperature on Heavy Metal Toxicity to Juvenile Crayfish, Orconectes immunis (Hagen). Environmental Toxicology. 21(5), 513-520.

Singh A., R.K. Sharma, M. Agrawal and F.M. Marshall. (2010): Risk Assessment of Heavy Metals Toxicity through Contaminated Vegetables from Water Irrigated area of Varanasi, India. Tropical Ecology. 51(25), 375-387. www.tropecol.com

Uwagboe A.I. and F.K. Hymore (2008): Heavy Metal Contamination of Roadside Soils, Stagnant pools and Sediments in Warri, Nigeria. Journal of Research in National Development. Vol. 6, No. $1,6 \mathrm{pp}$

Zahir E., I. I. Naqvi and S. M. Uddin (2009): Market Basket Survey of Selected Metals in Fruits from Karachi City (Pakistan). Journal of Basic and Applied Sciences. Vol.5 No.2, 47-52. 